\title{
MENANAMKAN NILAI AGAMA PADA ANAK USIA DINI DI PENGARUH MEDIA IKLAN MAKANAN TERHADAP POLA MAKAN ANAK USIA 4-6 TAHUN \\ Hanna Fakhriyah ${ }^{1} ;$ Suwardi $^{1}$
}

${ }^{1}$ Program Studi Pendidikan Guru Pendidikan Anak Usia Dini, Fakultas Psikologi dan Pendidikan, Universitas Al Azhar Indonesia, Jalan Sisingamangaraja Kebayoran baru, Jakarta Selatan 12110

Penulis untuk Korespondensi/E-mail: suwardi@uai.ac.id

\begin{abstract}
Abstrak - Metode penelitian yang digunakan yaitu penelitian kuantitatif dengan pendekatan survey. Teknik pengambilan data menggunakan kuesioner (angket). Pengambilan data dilakukan di Taman Kanak-Kanak yang berada lingkungan Pancoran sebanyak 3 lembaga dengan subjek penelitian adalah orang tua. Analisis data menggunakan uji normalitas, uji persamaan regresi linear sederhana, uji linearitas dan uji analisis determinasi. Data yang sudah diklasifikasikan, disajikan dan ditampilkan dalam bentuk tabel atau grafik. Hasil pengolahan data diketahui bahwa media iklan makanan memiliki nilai signifikansi sebesar 0,431 terhadap pola makan anak usia 4-6 tahun. Untuk uji linier sederhana mendapatkan hasil olah data $\mathrm{Y}=1,520+2,047 \mathrm{X}$ sedangkan uji analisis determinasi mendapatkan perolehan data sebesar $6,7 \%$ pengaruh variabel media iklan makanan terhadap pola makan anak usia 4-6 tahun. Kesimpulannya adalah terdapat pengaruh media iklan makanan terhadap pola makan anak usia 4-6 tahun di taman kanak-kanak di Kelurahan Pancoran. Adapun saran yang diberikan adalah bagi orang tua untuk dapat menambah pengetahuan tentang pemberian menu utama dengan cara menyusun menu utama secara variasi dari rasa, jenis dan bentuknya, sehingga anak tertarik untuk makan makanan yang disajikan di rumah. Bagi guru sebaiknya selalu mengingatkan kepada anak murid dan orang tua untuk membawa makanan yang sehat dan bergizi, dan bagi pengelola sekolah yang belum membuat jadwal menu sehat atau makan bersama dengan menu-menu yang bergizi setiap bulan bahkan disetiap minggunya.
\end{abstract}

Kata kunci : Media iklan makanan dan pola makan

Abstract - The research method used is quantitative research with a survey approach. Data collection techniques using a questionnaire (Questionnaire). Data was collected in kindergartens in the Pancoran environment as many as 3 institutions with the research subjects as parents. Data analysis used normality test, simple linear regression equation test, linearity test and determination analysis test. Data that has been classified, presented and displayed in the form of tables or graphs. The results of data processing note that the food advertising media has a significance value of 0.431 on the eating patterns of children aged 4-6 years. For a simple linear test, the results of data processing $Y=1.520+2.047 X$, while the analysis test of determination gets a data acquisition of $6.7 \%$ the influence of the food advertising media variable on the eating patterns of children aged 4-6 years. The conclusion is that there is an influence of food advertising media on the eating patterns of children aged 4-6 years in kindergartens in Pancoran Village. The advice given is for parents to be able to increase knowledge about the provision of the main menu by compiling the main menu in a variety of flavors, types and shapes, so that children are interested in eating food served at home. bBgi teachers should always remind students and parents to bring healthy and nutritious food, for school managers who have not made a healthy menu schedule or shared meals with nutritious menus every month and even every week.

Keywords: Media advertising food and eating patterns 


\section{PENDAHULUAN}

$\mathrm{A}$ nak usia dini adalah individu yang sedang mengalami proses pertumbuhan dan perkembangan yang sangat pesat ditandai lebih $80 \%$ otak anak mengalami perkembangan pada usia 0-6 tahun. Pada usia inilah disebut fase emas tumbuh kembang anak, segala informasi mengenai kata-kata atau perilaku orang baik-buruk disekitar akan diserap seluruhnya dan akan menjadi dasar terbentuknya karakter, kepribadian, serta kemampuan kognitif, dan juga keberlangsung kematangan fungsi fisik dan psikis yang siap memberi respon pada stimulasi yang diberikan lingkungan di sekitarnya. Dalam Undang-undang Nomor 23 Tahun 2002 mengenai perlindungan anak pasal 4 menyatakan bahwa: Setiap anak berhak untuk dapat hidup, tumbuh, berkembang, dan berpartisipasi secara wajar sesuai dengan harkat dan martabat kemanusiaan, serta mendapat perlindungan dari kekerasan dan diskriminasi. Anak mendapatkan hak untuk hidup, tumbuh dan berkembang maka, harus diberikan kelangsungan hidup yang baik oleh orang tua. Kemudian untuk bisa tumbuh dan berkembang juga diperlukan salah satunya dari asupan gizi.

Orang tua perlu memperhatikan asupan gizi yang dibutuhkan oleh anak, sehingga dapat mendukung tumbuh kembang anak secara optimal. Asupan gizi merupakan pemenuhan kebutuh gizi yang diperlukan oleh tubuh seseorang. Untuk memperoleh status gizi yang baik, maka asupan gizi dan pengeluarannya harus seimbang. Bila terdapat anak dengan kurang gizi pertumbuhannya akan lambat. Sedangkan jika terdapat anak dengan kelebihan gizi mengakibatkan kegemukan atau obesitas (Proverawati, 2011).

Di dalam buku yang dikeluarkan oleh Departemen Gizi dan Kesehatan Masyarakat (2011) fungsi umum asupan gizi adalah sebagai sumber energi atau tenaga, menyumbang pertumbuhan badan, memelihara jaringan tubuh, mengatur metabolisme dan mengatur keseimbangan air, mineral dan asam-basa di dalam cairan tubuh, dan juga berperan dalam mekanisme pertahanan tubuh terhadap penyakit sebagai antibody dan antitoksin. Berdasarkan pendapat tersebut, fungsi asupan gizi yaitu sebagai sumber energi pertumbuhan dan juga sebagai pertahanan tubuh dari berbagai penyakit.

Asupan gizi yang baik dapat diperoleh melalui makanan yang bergizi dan juga bervariasi. Makanan yang diberikan, disesuaikan juga dengan kebutuhan gizi anak. Menu makanan yang diberikan untuk anak perlu diganti setiap harinya, baik itu makanan pokok, lauk pauk, buah-buahan, sayur-sayuran atau makanan pendamping. Tidak hanya menyediakan makanan bergizi tetapi orang tua perlu mengenalkan berbagai macam jenis makanan bergizi, contohnya salah satu jenis makanan dari kedelai yaitu tempe dan tahu. Kedua makanan tersebut tidak hanya disajikan dengan cara menggoreng tetapi dapat juga disajikan dengan cara dibuat yang lainnya dapat berupa mengola makanan tersebut dengan bervariasi seperti steak tempe dan juga tahu lumpia.

Makanan bergizi harus dikonsumsi oleh anak setiap hari, sehingga membentuk pola makan yang sehat. Pola makan adalah susunan makanan yang biasa dimakan mencakup jenis dan jumlah bahan makanan yang dikonsumsi seseorang atau kelompok orang/ penduduk dalam frekuensi dan jangka waktu tertentu (Kementrian Kesehatan RI, 2011). Cara lainnya yaitu mengenalkan makanan bergizi pada anak bisa melalui lagu-lagu yang dinyanyikan sebelum anak makan atau menceritakan beberapa cerita tentang manfaat makanan bergizi. Mengenalkan makanan bergizi pada anak bertujuan supaya anak suka, lalu mau mencobanya dan mengkonsumsi setiap harinya sehingga makanan bergizi tersebut selalu ada di menu makan sehari-hari.

Makanan adalah salah satu produk yang diiklankan melalui televisi, yang salah satu sasarannya adalah anak-anak. Agar anak tertarik dengan produk yang ditawarkan maka iklan dibuat semenarik mungkin. Produsen makanan memperlihatkan produk dengan berbagai variasi tampilan mulai dari warna, bentuk juga kemasan yang menarik. Cara lain yang dilakukan oleh para pengiklan adalah memberikan mainan kecil yang dimasukan atau ditempelkan pada produk yang dijual.

Hasil riset yang dilakukan Purwaningwulan (2013) diketahui bahwa usaha produsen makanan menayangkan iklan makanan di televisi cukup efektif untuk mendorong anak 
membeli produk yang diiklankan. Melekatnya pengaruh produk yang diiklankan pada anak diakibatkan diantaranya karena lamanya waktu yang digunakan anak untuk menonton televisi. Wahyudi (2013) menuliskan bahwa rata-rata anak menghabiskan waktu antara 3-3.5 jam per hari untuk menonton tayangan televisi termasuk satu jam tayangan iklan. Selama setahun, seorang anak menyaksikan 25.000 iklan di televise dan $90 \%$ dari iklan itu ditujukan langsung untuk anak-anak dan menyajikan makanan-makanan bergizi rendah.

\section{Media Iklan}

Menurut Rahman (2019), iklan adalah prosesn yang mengeluarkan biaya besar, pada tingkat dan bentuk tertentu. Iklan atau advertising dapat didefinisikan sebagai "any paid from of nonpersonal communication about on organization product, service, or idea by an identified sponsor" (setiap bentuk komunikasi nonpersonal mengenai suatu organisasi, produk, servis atau ide yang dibayar oleh satu sponsor yang diketahui). Adapun maksud dibayar pada definisi tersebut menunjukkan bahwa ruang atau waktu bagi suatu pesan iklan pada umumnya harus dibeli. Maksud kata nonpersonal berarti suatu iklan melibatkan media massa (TV, radio, majalah, koran) yang dapat mengirimkan pesan kepada sejumlah besar kelompok individu pada saat bersamaan.

Kata iklan (advertising) berasal dari Bahasa Yunani yang artinya kurang lebih adalah "menggiring orang pada gagasan". Adapun periklanan secara komprehensif adalah semua bentuk aktifitas untuk menghadirkan dan mempromosikan ide, barang, atau jasa secara non personal yang dibayar oleh sponsor tertentu (Puspitasari, 2009).

Tujuan iklan adalah untuk meningkatkan penjualan, selain itu tujuan iklan juga dapat membentuk citra produk yang diproduksi oleh perusahaan atau memperkenalkan produk kepada konsumen sehingga, konsumen yang sebelumnya tidak tahu akan suatu produk, menjadi tahu akan keberadaan produk, diharapkan menumbuhkan kesadaran merk.

Tujuan periklanan menurut Shimp (2003), meliputi:

1. Memberi informasi (Informing) Periklanan membuat konsumen sadar (aware) akan merekmerek baru, mendidik mereka tentang berbagai fitur dan manfaat merek, serta memfasilitasi penciptaan merek yang positif.

2. Mempersuasi (Persuading) Periklanan yang efektif akan mampu mempersuasi (membujuk) pelanggan untuk mencoba produk dan jasa yang diiklankan. Terkadang persuasi berbentuk mempengarui permintaan primer, yakni menciptakan permintaan bagi keseluruhan kategori produk. Lebih sering iklan berupaya membangun permintaan sekunder, yakni permintaan bagi merekmerek perusahaan yang spesifik.

3. Mengingatkan (Reminding) Iklan menjaga agar merek perusahaan tetap segar dalam ingatan konsumen. Periklanan yang efektif juga meningkatkan minat konsumen terhadap merek yang sudah ada dan pembelian sebuah merek yang mungkin tidak akan dipilihnya.

4. Menambah Nilai (Adding Value) Periklanan member nilai tambah pada merek dengan mempengarui persepsi konsumen. Periklanan yang efektif menyebabkan merek dipandang sebagai lebih elegan, lebih bergaya, lebih bergengsi, dan lebih unggul dari tawaran pesaing. 20

5. Mendampingi (Assisting) Peran lain dalam periklanan adalah membantu perwalian penjualan. Iklan mengawali proses penjualan produk-produk perusahaan dan memberikan pendahuluan yang bernilai bagi wiraniaga sebelum melakukan kontak personal deng pelanggan yang prospektif. Upaya, waktu, dan biaya periklanan dapat dihemat karena lebih sedikit waktu yang diperlukan untuk memberi informasi kepada prospek tentang keistimewaan dan keuntungan produk. Terlebih lagi, iklan melegitimasi atau membuat apa yang dinyataan (klaim) oleh perwakilan penjualan menjadi lebih kredibel (lebih dapat dipercaya) menyampaikan pesan yang bersifat persuasif.

Kotler dan Keller (2012), mengungkapkan daya tarik iklan harus mempunyai tiga sifat : Pertama, iklan harus bermakna (meaningfull), menunjukkan manfaat-manfaat yang membuat produk lebih diinginkan atau lebih menarik bagi konsumen. Kedua, pesan iklan harus dapat dipercaya (believable), konsumen percaya bahwa produk tersebut akan memberikan 
manfaat seperti yang dijanjikan dalam pesan iklan. Ketiga, khusus (distinctive) bahwa pesan iklan lebih baik dibandingkan dengan iklan merk lainnya.

Iklan televisi mempunyai beberapa kelebihankelebihan. Kelebihan iklan televisi antara lain: dapat dinikmati oleh siapa saja, waktu dan siarannya sudah tertentu dan dapat memberikan kombinasi antara suara dengan gambar yang bergerak (Swastha, 2000). Salah satu saluran komunikasi yang saat ini mempunyai keunggulan kompetitif, bahkan mampu menggeser peran media massa lainnya dalam meraih di bidang iklan adalah televisi. Hal ini karena kecepatan dan daya Tarik televisilah yang menyebabkan media ini menjadi banyak pilihan perusahaan dalam mengkomunikasikan produknya.

Ada tiga kekuatan yang menyebabkan televisi menjadi pilihan dalam beriklan menurut Sumartono (2010), sebagai berikut :

1. Dampak yang kuat, dengan tekanan pada dua indera yaitu pengelihatan dan pendengaran, televisi mampu menciptakan kelenturan bagi pekerjaan-pekerjaan kreatif dengan mengkombinasikan gerakan, keindangan, suara, warna, drama dan humor.

2. Pengaruh yang kuat, televisi mempunyai pengaruh yang kuat untuk mempengaruhi persepsi audience. Kebanyakan calon pembeli lebih percaya pada perusahaan yang mengiklankan produknya di televisi daripada yang tidak sama sekali.

3. Efesiensi biaya, kemampuan untuk menjangkau khalayak sasaran yang sangat luas merupakan salah satu keunggulan yang tidak dimiliki oleh media lainnya. Jangkauan massal inilah yang menimbulkan efesiensi biaya untuk menjangkau setiap kepala.

Sumber pesan iklan televisi yang dapat dijadikan stimulus iklan menurut Hackley (2005), dapat dijelaskan sebagai berikut: Kualitas Gambar, adalah suatu tayangan iklan yang dilihat pemirsa atau masyarakat yang meliputi objek figur, lokasi dan latar belakang yang dipakai. Penilaian gambar merupakan persepsi pemirsa terhadap gambar atau objek yang ditampilkan pada saat iklan ditayangkan, baik pada media cetak maupun media elektronik (TV atau Web iklan di internet).
Gambar adegan tayangan iklan hendaknya memiliki kualitas yang baik dan mampu memberikan informasi pesan iklan dengan baik. Tema iklan adalah konsep dari iklan yang dapat dibaca, diingat dan akan melekat dalam ingatan pemirsa. Penilaian tema merupakan persepsi pemirsa terhadap sesuatu yang ditampilkan pada saat iklan ditayangkan di TV, yang mampu mendukung manfaat produk. Tema yang ditampilkan hendaknya dibuat sesederhana mungkin dan wajar, tetapi dapat mengungkapkan pesan sehingga tidak terlalu memancing imajinasi pemirsa. Manusia atau pemirsa menghendaki gagasan yang wajar tetapi cerdas, sehingga mudah diingat dan menarik perhatian. Lalu musik adalah alunan lagu yang berirama, naik dari suara manusia maupun dari alat-alat. Musik dapat berupa jingle (bunyi-bunyian) atau musik latar belakang. Penilaian musik merupakan persepsi pemirsa terhadap irama atau lagu yang diperdengarkan pada saat iklan ditayangkan di media iklan. Nyanyian membuat kata-kata lebih mudah diingat karena iramanya. Musik latar, jingle, lagu-lagu dan aransemen klasik digunakan untuk menarik perhatian, meyalurkan pesan-pesan penjualan, menentukan tekanan emosional dan mempengaruhi suara hati pendengar. Musik membentuk berbagai fungsi komunikasi meliputi cara untuk menarik perhatian, menjadikan konsumen berada dalam perasaan positif, membuat konsumen lebih dapat menerima pesan-pesan dalam iklan dan bahkan mengkomunikasikan arti produk yang diiklankan. Dan yang terakhir yaitu bintang iklan, bintang iklan adalah selebriti atau orang yang menjadi tokoh utama dalam suatu iklan televisi. Konsumen biasanya akan lebih tertarik membeli suatu produk apabila artis yang disukainya membintangi iklan produk tersebut.

\section{Pola Makan}

Menurut Hartono (2005), pengertian pola makan adalah tingkah laku manusia atau sekelompok manusia dalam memenuhi kebutuhan akan makan yang meliputi sikap, kepercayaan dan pilihan makan. Sikap biasanya ditandai dengan penilaian seseorang mengenai kesukaan dan ketidaksukaanya. Misalnya, seorang anak tidak menyukai pisang karena aromanya, maka ia tidak mengambil pisang sebagai makanannya. Hal tersebut didasari oleh ketidaksukaannya dengan aroma buah pisang. 
Sedangkan kepercayaan merupakan keyakinan bahwa sesuatu yang dipercayai itu benar. Misalnya, di dalam agama Islam tidak diperbolehkan memakan makanan yang diharamkan seperti daging babi, minuman khamar dan darah bangkai. Sementara, pilihan makanan merupakan jenis-jenis makanan yang tersedia untuk dihidangkan.

Di dalam buku yang dikeluarkan oleh Departemen Kesehatan RI (2009), pola makan adalah suatu cara usaha dalam pengaturan jumlah dan jenis makanan dengan maksud tertentu seperti mempertahankan kesehatan, status nutrisi, mencegah atau membantu kesembuhan penyakit. Makanan yang dimakan dalam keseharian berdampak pada kondisi kesehatan seseorang.

Pola makan akan mempengaruhi penyusunan menu. Menu adalah susunan makanan yang dimakan oleh seseorang untuk sekali makan atau untuk sehari-hari. Kata "menu" bisa diartikan "hidangan". Menu seimbang adalah menu yang terdiri dari beraneka ragam makanan dalam jumlah dan proporsi yang sesuai, sehingga memenuhi kebutuhan gizi seseorang guna pemeliharaan dan perbaikan sel-sel tubuh dan proses kehidupan serta pertumbuhan dan perkembangan (Almatsier, 2005).

Perilaku sangat mempengaruhi seseorang dalam bertingkah laku. Menurut Notoadmojo (2007), perilaku dipengaruhi oleh 3 faktor utama yaitu :

1. Faktor Predisposisi, yaitu: faktor pencetus timbulnya perilaku seperti: umur, pengetahuan, pengalaman, pendidikan, sikap dan lain sebagainya. Contohnya, anak usia 5 tahun menyukai makan makanan yang disenangi yaitu makan permen. Karena yang anak itu sudah pernah mencicipi permen dan permen itu memiliki rasa yang manis sehingga anak tersebut tidak jarang memakan permen tersebut.

2. Faktor Pendukung, yaitu: factor yang mendukung timbulnya perilaku seperti: lingkungan fisik, dana dan sumber daya yang ada di masyarakat. Contohnya, Banyaknya hal yang menyediakan makanan permen tersebut seperti, warung atau minimarket yang berlokasi di daerah tempat tinggalnya, membuat anak sering membeli dan memakan permen. Ditambah orang tua yang tidak melarang anak untuk jajan apapun yang dia inginkan, terlebih kepada orang tua yang memiliki dana penghasilan yang cukup banyak.

3. Faktor Pendorong, yaitu: faktor yang memperkuat atau mendorong seseorang untuk berperilaku yang berasal dari orang lain misalnya, teman. Contohnya, lingkungan sangat berdampak terhadap sikap dan perilaku anak yang dilakukannya, terlebih saat bermain dengan temantemannya. Dimana setiap hari temannya selalu makan permen dan sudah pasti ia akan memiliki keinginan untuk mencoba makan permen bersama temannya tersebut.

\section{Pola Makan Anak Usia 4-6 Tahun}

Masa prasekolah adalah masa paling penting bagi proses tumbuh kembang anak. Oleh karena itu, nutrisi tepat dan sehat sangat dibutuhkan untuk anak. Kebiasaan pola makan yang sehat harus dikenalkan pada anak sejak dini. Pola makan tepat dan sehat yang dikenalkan sejak dini nantinya akan diterapkan si anak jika si anak dewasa.

Menurut Ulfah (2009), kebutuhan nutrisi bagi anak prasekolah adalah karbohidrat sebagai sumber energi pemenuhannya sebesar 220 gram. Aktifitas anak prasekolah sangatlah banyak, untuk itu konsumsi makanan yang kaya karbohidrat sangat dibutuhkan. Hampir setengah dari total kalori yang dibutuhkan anak prasekolah berasal dari makanan yang berkarbohidrat. Protein merupakan zat gizi yang dibutuhkan oleh tubuh sebagai penentu pertumbuhan. Protein juga membangun dan memperbaiki jaringan tubuh dibutuhkan sebesar 35 gram. Zat gizi lainnya adalah lemak, lemak juga merupakan sumber energi bagi tubuh, kebutuhannya sebesar 62 gram.

Beberapa hal yang harus diperhatikan dalam pemberian makan anak usia prasekolah menurut Soenardi (2006), sebagai berikut yaitu selalu variasikan mekanan yang diberikan, variasikan cara mengolah, berikan air putih setiap kali habis makan, dan hindari memberikan makanan selingan mendekati jam makan utama lalu jelaskan menfaat makanan yang harus dimakan sehingga dapar mengurangi rasa tidak sukanya.

Pemenuhan kebutuhan nutrisi anak prasekolah memerlukan perhatian dan ketelatenan orang 
tua, dalam proses penerapan pola konsumsi makanan yang baik. Nutrisi yang bergizi merupakan salah satu faktor penting untuk menjaga kesehatan tubuh. Begitupula pada anak prasekolah membutuhkan nutrisi yang bergizi untuk pertumbuhan dan perkembangan fisik serta otaknya. Nutrisi yang bergizi akan mendukung perkembangan mental dan sosial anak.

Menurut Soenardi (2005), menolak makanan merupakan cara pertama anak untuk melenturkan otot dan menyatakan keinginannya yang bebas. Sikap penolakan makan menjadi masalah, namun seorang ibu tak perlu terburuburu menanggapinya sebagai masalah bila cara yang tepat untuk menghadapinya belum dicari. Masalah makan yang terjadi pada umumnya adalah kesulitan makan, karena dari hari ke hari umumnya nafsu makannya tidak menentu.

Pemenuhan kebutuhan nutrisi anak prasekolah memerlukan perhatian dan ketelatenan orang tua, dalam proses penerapan pola konsumsi makanan yang baik. Nutrisi yang bergizi merupakan salah satu faktor penting untuk menjaga kesehatan tubuh. Begitupula pada anak prasekolah membutuhkan nutrisi yang bergizi untuk pertumbuhan dan perkembangan fisik serta otaknya. Nutrisi yang bergizi akan mendukung perkembangan mental dan sosial anak. Berikut adalah bagian-bagian penting dalam penerapan pola konsumsi menurut (Santoso, 2000).

\section{Penyusunan Menu}

Menu adalah susunan hidangan sekali makan yang secara keseluruhan harmonis dan saling melengkapi untuk kebutuhan seseorang, umumnya menu disusun oleh ibu. Menu sehari berarti susunan hindangan untuk satu hari, terdiri dari beberapa waktu makan yaitu makan pagi, makan siang, makan malam serta makan selingan antara makan pagi dengan makan siang serta makan siang dengan makan malam.

Penyusunan menu sebaiknya memperhatikan hal-hal mengenai kombinasi rasa (asan, manis, asam, pedas), kombinasi warna (merah, hijau, kuning, dsb), variasi bentuk potongan (panjang, pendek, dll), variasi kering atau berkuah dan variasi teknik pengolahan (goreng, rebus, dll).

\section{Menu Menurut Waktu Makan}

Jadwal pemberian makan anak dapat dijadikan sebagai salah satu faktor penentu kesehatannya, makan terbagi ke dalam beberapa hal yaitu makanan utama dan makanan selingan.

\section{a. Makanan Utama}

Makanan utama merupakan makanan yang memegang peranan penting. Makanan utama dapat dikenal dari makanan yang dihidangkan pada waktu makan pagi, siang, atau malam. Pada umumnya porsi makanan utama terlihat lebih banyak dari bahan makanan lainnya (makanan selingan). Bahan makanan utama merupakan sumber energi (kalori) dan mengandung banyak karbohidrat. Beberapa jenis makanan utama juga memberikan zat protein yang cukup besar jumlahnya dalam konsumsi seseorang.

Berikut ini merupakan contoh menu seimbang dalam sehari untuk anak usia 4-6 tahun menurut (Soenardi, 2005). Contoh menu utama

1) Sarapan pagi: Nasi, telur dadar, sup kacang merah.

2) Makan siang: Nasi, pepes ikan, tempe bacem, sup sayuran campur, papaya.

3) Makan malam: Nasi, ayam goreng, sup kembang tahu, jeruk.

\section{b. Makanan Selingan}

Makanan selingan mempunyai peranan penting, terutama bila anak tidak cukup mengkonsumsi porsinya dari makanan utama, yaitu makan pagi, siang, dan malam. Makanan selingan adalah jajanan makanan yang diberikan diantara waktu makan. Makanan selingan bisa membantu bila anak susah makan. Namun, pemberian yang berlebihan pada makan selingan tidak baik, karena menganggu nafsu makan anak pada saat makan utamanya.

Makanan selingan sebaiknya diberikan jauh sebelum waktu makan, misalnya antara jam (09.00-10.00) dan sore hari antara jam (15.0016.00), jenis makanan selingan yang perlu diperhatikan, yaitu: yang mengandung sumber zat tenanga (karbohidrat), zat pembangun (protein) dan zat pengatur (vitamin dan mineral). Contohnya: siomay ikan dan sayuran, risoles isi ayam, salad keju buah, pizza brokoli, dan lain-lain.

Anak-anak menyukai makanan yang manis untuk dijadikan makanan selingan. Menurut 
Damayanti (2010), makanan manis mengandung banyak gula dan bisa memunculkan berbagai gangguan kesehatan. Anak usia sekolah khususnya anak sekolah dasar adalah satu kelompok yang rentan terhadap penyakit gigi dan mulut. Makanan selingan ada yang terdiri dari sumber kalori saja seperti gula dan tepung, contohnya: gula permen, manisan, es sirup, coklat dan lain-lain.

Hal ini merupakan makanan selingan yang kurang baik, karena akan menganggu nafsu makan dan dapat merusak gigi. Kecendrungan makanan manis sejak kecil akan dibawa sampai dewasa yang akan berpengaruh pada kesehatan tubuh, yaitu menyebabkan kegemukan yang mempunyai resiko terhadap penyakit.

Berdasarkan penelitian sebelumnya, yang dilakukan oleh Herdanu (2017) mengenai pengaruh daya tarik iklan makanan instan di televisi terhadap perilaku konsumsi makanan pada mahasiswa kos, serta berdasarkan beberapa keterangan singkat tersebut, maka akan dilakukan penelitian dengan judul Pengaruh Media Iklan Makanan Terhadap Pola Makan Anak Usia 4-6 Tahun.

Adapun tujuan dari penulisan penelitian ini yaitu untuk mengetahui ada tidaknya pengaruh media iklan makanan terhadap pola makan anak usia 4-6 tahun di Taman Kanak-Kanak di Kelurahan Pancoran.

\section{METODE PENELITIAN}

Metode penelitian yang dilakukan dalam penelitian ini adalah metode kuantitatif. Kuantitaif adalah penelitian yang menjelaskan diawali dengan kerangka teori, pemikiran dari para ahli hingga pemecahan permasalahan untuk memperoleh pembenaran suatu penelitian. Alat pengambilan data dalam penelitian ini menggunakan kuesioner atau angket. Kuesioner atau angket merupakan teknik pengumpulan data yang dilakukan dengan cara memberi seperangkat pertanyaan atau pernyataan tertulis kepada responden untuk dijawab (Sugiyono, 2018).

Alat pengambilan data dalam penelitian ini menggunakan kuesioner atau angket. Kuesioner atau angket merupakan teknik pengumpulan data yang dilakukan dengan cara memberi seperangkat pertanyaan atau pernyataan tertulis kepada responden untuk dijawab (Sugiyono, 2018).

\section{HASIL DAN PEMBAHASAN}

Penelitian ini dilakukan di Taman KanakKanak di Kelurahan Pancoran Kecamatan Pancoran. Taman Kanak-Kanak yang dipilih adalah yang bertempat tinggal di Kelurahan Pancoran. Taman Kanak-Kanak di Kelurahan Pancoran berjumlah 6 lembaga, dengan jumlah wali murid sebanyak 145 orang. Penelitian ini hanya menggunakan 3 lembaga Taman KanakKanak untuk pengambilan data uji coba dan data sebenarnya.Sampel pada penelitian ini adalah para orang tua yang anaknya bersekolah di Lembaga Taman Kanak-kanak di Kelurahan Pancoran dengan jumlah 60 responden, yang berasal dari berbagai latar belakang pendidikan, jenis kelamin, usia, pekerjaan, tingkat ekonomi, serta lembaga PAUD yang dipilih untuk tempat bersekolah anaknya.

Hasil dari uji normalitas adalah jika nilai signifikansi lebih besar dari 0.05 maka data tersebut berdistribusi normal. Sebaliknya jika nilai signifikasnsi lebih kecil dari 0.05 maka dat tersebut tidak berdistribusi normal, dan diketahui diketahui bahwa variabel pengaruh media iklan makanan dan variabel pola makan anak usia 4-6 tahun memiliki nilai signifikansi sebesar 0.431 dimana kedua variabel tersebut memiliki nilai signifikansi yang lebih besar dari 0.05. Itu artinya data dalam penelitian ini bersdistibusi normal, dengan demikian maka data dalam tersebut dapat digunakan untuk diambil infrensinya.

Hipotesis yang diuji berbunyi "Terdapat Pengaruh Media Iklan Makanan Terhadap Pola Makan Anak Usia 4-6 Tahun di Taman KanakKanak di Kelurahan Pancoran”. Untuk menguji hipotesis tersebut digunakan statistik uji regresi linear sederhana. Hasil dari analisis data antara variabel pengaruh media iklan makanan $(\mathrm{X})$ terhadap pola makan anak usia 4-6 tahun (Y) diperoleh model persamaan regresi yaitu $\mathrm{Y}=$ $1.520+2.047 \mathrm{X}$. Dengan penjelasan sebagai berikut: $\mathrm{a}=$ angka konstan dari unstandardized coefficients. Dalam kasus ini nilainya sebesar 1,520. Maka dengan demikian dapat dikatakan bahwa setiap kenaikan dalam pengaruh media iklan makanan $(\mathrm{X})$ akan menaikkan pola makan anak usia 4-6 tahun (Y) sebesar 2.047 pada nilai awal 1.520. Karena nilai koefisien regresi 
bernilai positif (+), maka dengan demikian dapat dikatakan bahwa pengaruh media iklan makanan $(\mathrm{X})$ berpengaruh positif terhadap pola makan anak usia 4-6 tahun. Untuk itu sebelum menentukan hipotesis penelitian maka dilakukan pengujian signifikansi dan linearitas regresi.

Hasil nilai data menunjukkan bahwa $\mathrm{k}=1$ (X: Pengaruh Media Iklan Makanan), dan $n=60$. Selanjutnya nilai dimasukkan ke dalam rumus, maka menghasilkan angka $(1 ; 60-1)=(1 ; 59)$, angka ini kemudian dijadikan acuan untuk mengetahui nilai $\mathrm{F}$ tabel yang berada di lampiran V. Nilai $F$ tabel yang didapat adalah 4.00. Maka dapat diketahui bahwa nilai $F$ hitung sebesar 4,192 dan nilai $\mathrm{F}$ tabel adalah sebesar 4,00. Karena nilai $\mathrm{F}$ hitung 4.192 lebih besar dari nilai $\mathrm{F}$ tabel 4,00, maka "Pengaruh Media Iklan Makanan (X) berpengaruh terhadap Pola Makan Anak Usia 4-6 Tahun (Y)" .

Menentukan hipotesis:

Ho: Terdapat hubungan linear variabel media iklan makanan dengan variabel pola makan anak usia 4-6 tahun.

Ha: Tidak terdapat hubungan linear variabel media iklan makanan dengan variabel pola makan anak usia 4-6 tahun.

Kriteria pengujian linearitas adalah jika nilai Linearity $=$ Sig. $<0.05$, maka hubungan antara variabel bebas terhadap variabel terikat adalah linear. Diketahui bahwa linearity sig $0.034<$ 0.05, maka dapat disimpulkan bahwa Ho diterima dan $\mathrm{Ha}$ ditolak, artinya persamaan regresi $\mathrm{Y}=1.520+2.047 \mathrm{X}$ linear.

Selanjutnya untuk mengetahui berapa besar sumbangan atau pengaruh media iklan makanan terhadap pola makan anak usia 4-6 tahun di Taman Kanak-Kanak dapat diketahui melalui koefisien determinasi dan hasilnya adalah nilai $\mathrm{R}$ square sebesar 0.067 . Nilai ini mengandung arti bahwa pengaruh media iklan makanan (X) terhadap pola makan anak usia 4-6 tahun (Y) adalah sebesar $6.7 \%$, sedangkan $93.3 \%$ pola makan anak usia 4-6 tahun dipengaruhi oleh variabel lain yang tidak dibahas dalam penelitian ini.

Berdasarkan hasil olah data mengenai media iklan makanan (X), dari 60 responden menujukkan kategori tinggi, dengan jumlah responden paling banyak, yaitu berjumlah 22 responden pada jarak interval 40.00-43.00. Tingginya daya beli dari media iklan makanan diperkuat dari hasil perhitungan karakteristik responden, dimana tingkat ekonomi dari responden pada penelitian ini didominasi oleh responden dengan tingkat ekonomi kategori tinggi dengan jumlah penghasilan >RP.3.000.000 per bulan dan jumlah responden dengan kategori tingkat ekonomi tinggi sebanyak 46 responden atau $76.7 \%$ dari keseluruhan responden. Tingkat ekonomi seseorang juga berkaitan dengan pemberian suatu produk makanan. Hal ini sejalan dengan yang dikemukakan oleh Sumartono (2010) bahwa daya tarik televisilah yang menyebabkan media ini menjadi banyak pilihan perusahaan dalam mengkomunikasikan produknya.

Sedangkan hasil olah data mengenai pola makan anak usia 4-6 Tahun (Y) dari 60 responden menunjukkan pada kategori sedang, dengan jumlah responden paling banyak, yaitu berjumlah 22 responden dengan jarak interval 57.00-63.00. Diperkuat dari hasil perhitungan karakteristik pekerjaan orang tua di Kelurahan Pancoran didominasi Ibu Rumah Tangga, yaitu sebanyak 25 responden atau sebesar $41.7 \%$. Suatu pekerjaan yang dilakukan mempengaruhi tingkat pengetahuan yang diterima di dalam lingkungan sekitar, pengetahuan yang dimiliki dan kurangnya proses belajar juga memengaruhi persepsi seseorang terhadap suatu objek atau peristiwa seperti faktor yang mempengaruhi pola pemberian makan kepada anak. Hal ini sejalan dengan yang dikemukakan oleh Notoadmojo (2007), perilaku dipengaruhi oleh 3 faktor utama yaitu: Faktor Predisposisi, yaitu: faktor pencetus timbulnya perilaku seperti: umur, pengetahuan, pengalaman, pendidikan, sikap dan lain sebagainya, faktor pendukung, yaitu: faktor yang mendukung timbulnya perilaku seperti: lingkungan fisik, dana dan sumber daya yang ada di masyarakat dan faktor pendorong, yaitu: faktor yang memperkuat atau mendorong seseorang untuk berperilaku yang berasal dari orang lain misalnya, teman.

Berdasarkan hasil analisis data hasil uji signifikansi menggunakan uji $\mathrm{F}$ didapatkan nilai $\mathrm{F}$ hitung sebesar 4.192 lebih besar dari nilai $\mathrm{F}$ tabel 4.00, maka media iklan makanan (X) berpengaruh signifikan terhadap pola makan anak usia 4-6 tahun (Y). Berdasarkan uji 
linearitas maka hubungan media iklan makanan terhadap dukungan pola makan anak usia 4-6 tahun adalah linear. Setelah dilakukan uji linearitas maka peneliti melakukan Uji R2 (uji determinasi) untuk mengetahui berapa besar pengaruh media iklan makanan $(\mathrm{X})$ terhadap pola makan anak usia 4-6 tahun (Y), diperoleh hasil $(r x y=0.260)$ antara pengaruh media iklan makanan terhadap pola makan anak usia 4-6 Tahun di Taman Kanak-Kanak.

Nilai R square sebesar square sebesar 0.067. Nilai ini mengandung arti bahwa pengaruh media iklan makanan $(\mathrm{X})$ terhadap pola makan anak usia 4-6 tahun (Y) adalah sebesar $6.7 \%$. Nilai yang mempengaruhi pola makan didapat karena adanya daya tarik iklan makanan, hal ini sesuai dengan penelitian Mita Kuroifah (2014) yang menunjukan bahwa terdapat "Pengaruh Daya Tarik Iklan Makanan Instan Di Televisi Terhadap Perilaku Konsumsi Makanan Pada Mahasiswa Kos". Yang menyebabkan anakanak tertarik pada iklan adanya daya tarik dari suatu pesan tayangan iklan, hal ini sejalan dengan yang dikemukakan oleh Mazwahid (2011), daya tarik yang dimiliki iklan ada tiga sifat yaitu meaningful (bermakna), bealivable (dipercaya) dan distinctive (khas). Iklan yang menarik adalah iklan yang mempunyai daya tarik, yaitu memiliki kemampuan untuk menarik pasar (audience) sasaran.

Hasil data penelitian bahwa media iklan makanan di Kelurahan Pancoran berada pada kategori tinggi didapat dari pernyataanpernyataan yang diajukan kepada orang tua melalui angket. Pernyataan-pernyataan pada angket untuk variabel media iklan makanan (X) dibuat untuk melihat sebagaimana besarnya pengaruh media iklan makanan yang terjadi dilingkungan. Dari 60 responden 83\% menjawab setuju pada butir pernyataan nomor 1 bahwa orang tua berpendapat anaknya tertarik untuk mencoba produk makanan setelah melihat tayangan iklan yang dibintangi oleh tokoh yang diidolakannya. Hal ini sejalan dengan yang dikemukakan oleh menurut Sumartono (2010) bahwa sumber pesan iklan antara lain yaitu bintang iklan atau orang yang menjadi tokoh utama dalam suatu iklan televisi. Konsumen biasanya akan lebih tertarik membeli suatu produk apabila artis yang disukainya membintangi iklan produk tersebut. Atau pada butir nomor 4 dengan hasil $83 \%$ responden menjawab setuju oleh pernyataan
"Anak saya tertarik untuk mecoba produk makanan setelah melihat tayangan iklan yang mengandung lagu dan gerakannya" untuk indikator ini juga memiliki skor yang tinggi dengan mayoritas menjawab setuju. Dari hasil pada butir pernyataan nomor 4 tersebut diketahui bahwa sumber iklan berpengaruh kepada konsumen seperti menurut Sumartono (2010) yaitu, Musik dalam tayangan iklan adalah alunan lagu yang berirama, naik dari suara manusia maupun dari alat-alat. Musik dapat berupa jingle (bunyi-bunyian) atau musik latar belakang.

Penilaian musik merupakan persepsi pemirsa terhadap irama atau lagu yang diperdengarkan pada saat iklan ditayangkan di media iklan. Nyanyian membuat kata-kata lebih mudah diingat karena iramanya. Musik latar, jingle, lagu-lagu dan aransemen klasik digunakan untuk menarik perhatian, meyalurkan pesanpesan penjualan, menentukan tekanan emosional dan mempengaruhi suara hati pendengar. Musik membentuk berbagai fungsi komunikasi meliputi cara untuk menarik perhatian, menjadikan konsumen berada dalam perasaan positif, membuat konsumen lebih dapat menerima pesan-pesan dalam iklan dan bahkan mengkomunikasikan arti produk yang diiklankan.

\section{SIMPULAN DAN SARAN}

Adapun kesimpulan yang peneliti tuliskan berjudul Pengaruh Media Iklan Makanan Terhadap Pola Makan Anak Usia 4-6 Tahun di Taman Kanak-Kanak di Kelurahan Pancoran, dapat diambil kesimpulan bahwa terdapat pengaruh antara media iklan makanan terhadap pola makan anak usia 4-6 tahun. Hasil kesimpulan diperkuat dari perolehan $\mathrm{R}$ square (R2) sebesar $6.7 \%$.

Adapun saran yang peneliti tuliskan hasil penelitian dan kesimpulan yang telah diuraikan di atas, maka dapat diberikan beberapa saran yaitu: 1). Bagi orang tua untuk dapat menambah pengetahuan tentang pemberian menu utama dengan cara menyusun menu utama secara variasi dari rasa, jenis dan bentuknya, 2). Bagi guru sebaiknya untuk selalu mengingatkan kepada anak murid dan orang tua untuk membawa makanan yang sehat dan bergizi, 3). Bagi pengelola sekolah yang belum membuat jadwal menu sehat atau makan bersama dengan 
menu-menu yang bergizi setiap bulan bahkan disetiap minggunya.

\section{DAFTAR PUSTAKA}

Almatsier, S. (2005). Prinsip dasar ilmu gizi. Jakarta: Gramedia Pustaka Utama.

Damayanti. (2010). Makanan anak usia sekolah dan tips memberi makan anak usia sekolah. Jakarta: Gramedia Pustaka Utama.

Depkes RI. (2011). Target tujuan pembangunan MDGs. Direktorat Jendral Kesehatan Ibu dan Anak. Jakarta

Departemen Kesehatan RI. (2009). UndangUndang Republik Indonesia Nomor: 23 tahun 2009 tentang kesehatan. Jakarta

Hackley, C. (2005). Advertising and Promotion: Communicating Brands. London: SAGE

Hartono. (2005). Hubungan konsumsi makanan, kebiasaan jajan, pola aktivitas fisik dengan status gizi siswa FKM UI. Depok.

Herdanu, Refky. (2017). Pengaruh iklan televisi terhadap minat beli pada produk susu Anlene PT. Fonterra Brand. Universitas Lampung.

Kuroifah, M. (2014). Pengaruh daya tarik iklan makanan instan di televisi terhadap perilaku konsumsi makanan pada mahasiswa kos. Universitas Negri Yogyakarta

Kotler dan Keller, K. L. (2012). Manajemen pemasaran. Jakarta: PT. Indeks

Notoadmodjo. (2007). Metodologi penelitian kesehatan. Jakarta: Rieke Cipta.

Proverawati, A dan Wati, E K. (2011). Ilmu gizi untuk perawat dan gizi kesehatan. Yulia Medika: Yogyakarta.

Purwaningwulan, M.M. (2013). Daya tarik pesan iklan humor. Majalah Ilmiah UNIKOM, Vol 10 No.1.
Rahman, A. (2010). Strategi dahsyat marketing mix for small business: Cara Jitu Merontokkan Pesaing. Jakarta: TransMedia Pustaka.

Santoso, Soegeng. (2008). Kesehatan dan gizi. Jakarta: Universitas Terbuka.

Soenardi, T., Tim Yayasan Gizi Kuliner Jakarta. (2013). Teori dasar kuliner. Jakarta: PT. Gramedia Pustaka Utama.

Sugiyono. (2012). Statistika untuk penelitian. Bandung: Alfabeta

Sugiyono. (2018). Metode penelitian kuantitatif, kualitatif, dan $R \& D$. Bandung: Alfabeta

Sumartono. (2010). Perangkap dalam iklan. Bandung: Alfabeta

Shimp, T.A. (2003). Periklanan promosi. Jakarta: Erlangga

Swastha. (2008). Manajemen pemasaran modern. Yogyakarta: Penerbit Liberty.

Soenardi. (2005). Makanan balita untuk tumbuh sehat dan cerdas. Jakarta: Gramedia Pustaka Utama

Wahyudi. (2013). Iklan televisi dan perilaku konsumtif anak-anak. Universitas Sultan Ageng Tirtayasa

(2002). Undang-Undang No. 23 Tahun 2002 tentang perlindungan anak.. Jakarta. 